\title{
KrzyszTOF CzICHY
}

\author{
Wyższa Szkoła Finansów i Prawa w Bielsku Białej
}

\section{DOBROWOLNE PODDANIE SIĘ ODPOWIEDZIALNOŚCI W PRAWIE KARNYM SKARBOWYM. UWAGI 'DE LEGE FERENDA'}

Dobrowolne poddanie się odpowiedzialności należy do najstarszych instytucji w polskim prawie karnym skarbowym. Już ustawa karna skarbowa z 2 sierpnia 1926 r. w art. 176 przewidywała, że obwiniony może „złożyć prośbę o zezwolenie na dobrowolne poddanie się karze, jeśli ofiarowuje karę pieniężną wraz z uznaniem konfiskaty przedmiotu przestępstwa oraz jeśli zrzeknie się formalnego orzeczenia karnego". Pomimo że z wydaniem każdej kolejnej ustawy karno skarbowej omawiana instytucja podlegała modyfikacji, to jednak jej istota pozostaje bez zmian. Za główne elementy jej mechanizmu, które zawsze występowały, uznaje się dobrowolność wniosku, zezwolenie właściwego organu i wywołanie skutków prawomocnego orzeczenia karnego ${ }^{1}$. Co bardzo istotne, dobrowolne poddanie się odpowiedzialności jest instytucją, której prawo karne skarbowe dopracowało się samodzielnie i która nie została przejęta $\mathrm{z}$ powszechnego prawa karnego ${ }^{2}$.

\footnotetext{
1 F. Prusak, Normatywne i pragmatyczne aspekty dobrowolnego poddania się karze «Nowe Prawo» 3/1980, s. 14, odnośnie ewolucji prezentowanej instytucji i jej kształtu w kolejnych ustawach por. I. ZGoLIŃski Dobrowolne poddanie się odpowiedzialności w prawie karnym skarbowym, Warszawa 2011, s. 17-60.

2 L. Wilk, J. ZagrodniK Kodeks karny skarbowy. Komentarz, Warszawa 2007,
} s. $89-90$. 
To właśnie na przykładzie dobrowolnego poddania się odpowiedzialności bardzo dobrze widać istotę priorytetu egzekucji nad represją, co uwidacznia się w uwarunkowaniu zastosowania tej instytucji od uiszczenia należności publicznoprawnej, w sytuacji gdy w związku z przestępstwem lub wykroczeniem skarbowym nastąpiło uszczuplenie takiej należności, a należność ta jest wymagalna.

Praktyka stosowania instytucji dobrowolnego poddania się odpowiedzialności była w ostatnim czasie przedmiotem badań prowadzonych w różnych miastach przez J. Sawickiego ${ }^{3}$ i I. Zgolińskiego ${ }^{4}$.

Pierwszy $z$ autorów swoje badania przeprowadził na terenie Wrocławia. Wynika z nich, że podstawowym powodem odmowy wniesienia do sądu wniosku o udzielenie zezwolenia na dobrowolne poddanie się odpowiedzialności, pomimo przeprowadzonych pomyślnie negocjacji, był bezskuteczny upływ terminu, w którym sprawca zobowiązany był uiścić uszczuploną należność publicznoprawną oraz kwotę uiszczoną tytułem kary grzywny. W okresie 2005 - 2009 r. negocjacje w sprawie dobrowolnego poddania się odpowiedzialności dotyczyły 55,5\% wszczętych spraw karnych skarbowych (jest to liczba 4060 spraw). Z tej liczby negocjacje zakończyły się skierowaniem wniosku do sądu o udzielenie zezwolenia na dobrowolne poddanie się odpowiedzialności aż w 99, $2 \%$ przypadków. Odmowa wniesienia takiego wniosku następowała sporadycznie i dotyczyła jedynie 33 przypadków. Odnotowano również bardzo małą liczbą zażaleń na odmowę skierowania do sądu stosownego wniosku. Średnia w odniesieniu do dwóch przebadanych organów nadrzędnych wyniosła $1,2 \%$ wszystkich spraw rozpoznawanych przez te organy w trybie nadzoru. Podstawą uchyleń było uznanie, że termin uiszczenia przez sprawcę obowiązkowych kwot nie ma charakteru terminu zawitego, stąd wpłata dokonana po upływie terminu nie musi stanowić bezwzględnej przeszkody zastosowania instytucji, zwłaszcza w tych przypadkach, gdy sprawca podał powód opóźnienia zasługujący w ocenie organu nadrzędnego na uwzględnienie. Jeżeli

3 J. SAWICKI, Zaniechanie ukarania jako element polityki karnej w prawie karnym skarbowym, Wrocław 2011.

4 I. ZgolińsKi, op. cit., s. 236-251. 
rozpatrywać natomiast decyzje sądu, to zgoda na dobrowolne poddanie się odpowiedzialności stanowiła $66,8 \%$ rozstrzygnięć. Autor podkreśla przy tym symboliczną ilość decyzji odmownych sądu (zaledwie 0,3\% spraw), co może rodzić obawę o zbyt rutynowy stosunek do tych spraw i ograniczenie działań do oceny przesłanek formalnych bez wnikliwej oceny np. stopnia społecznej szkodliwości czynu. Badania dotyczące wysokości kwoty uiszczanej tytułem kary grzywny wykazały, że najwięcej, bo prawie 35\%, stanowiły kwoty w wysokości od 201 do $500 \mathrm{zł}$. Na drugim miejscu były grzywny do 200 zł (w 31,7\% przypadków), co powoduje, że w ponad połowie przypadków $(66,7 \%)$ uiszczono kwoty do 500 zł. Wyższe kwoty, od 501 zł do 800 zł to 12,9\%, zaś od 801 do 1200 zł to dalsze $10,9 \%$ przypadków. W pozostałych przypadkach wystąpiły kwoty wyższe niż 1200 zł (9,5\%). Autor podkreśla, że kwoty do 1200 zł stanowiły $90,5 \%$ wszystkich grzywien ${ }^{5}$.

Z kolei I. Zgoliński swoje badania przeprowadził na terenie Bydgoszczy. Oceniając stosowanie dobrowolnego poddania się odpowiedzialności, doszedł do wniosku, że praktyka wypaczyła korzystanie z tej instytucji. W szczególności niezgodny z założeniami ustawodawcy jest sam przebieg negocjacji, co podyktowane jest zdaniem autora chęcią przyspieszenia postępowania oraz zagwarantowania swoistej „wygody” w działaniu organów finansowych, a tym samym ich mniejszego nakładu pracy. Organ bowiem już na początku informuje sprawcę, na jakich warunkach będzie mógł ubiegać się o zezwolenie na dobrowolne poddanie się odpowiedzialności i skorzystać z niego, oraz co musi uczynić, jeśli chce w ten sposób zakończyć sprawę. Z uzyskanych informacji wynika, że to oskarżyciel skarbowy proponuje sprawcy wysokość kwoty, którą ma wpłacić tytułem grzywny. Nie jest to kwota ostateczna, gdyż musi ją następnie uzgodnić z naczelnikiem urzędu. Wyniki tego uzgodnienia sprawca może zaakceptować lub nie i w zależności od tego organ, podtrzymując swoje stanowisko w kwestii sprawstwa, sporządza wniosek o zezwolenie na dobrowolne poddanie się odpowiedzialności albo akt oskarżenia czy inną decyzję. W takiej sytuacji uzasadniony wydaje się

5 J. SAWICKI, op. cit. s. 328-338. 
powrót do możliwości orzekania przez sądy tytułem kary grzywny kwoty niższej niż uzgodniona przez sprawcę $z$ organem finansowym ${ }^{6}$.

Z informacji uzyskanych w II Śląskim Urzędzie Skarbowym w Katowicach wynika, że w 2009 r. zostało wszczętych 240 spraw karnych skarbowych, w tym 13 o czyny określone w ustawie o rachunkowości. $\mathrm{Z}$ tej liczby jedynie 35 spraw zakończyło złożeniem wniosku o zezwolenie na dobrowolne poddanie się odpowiedzialności, a zatem jedynie w 14,6\% spraw. W 2010 r. zostało wszczętych spraw 280 spraw, w tym również $13 \mathrm{z}$ rachunkowości. W tym roku jedynie 38 spraw zakończyło się złożeniem wniosku o dobrowolne poddanie się odpowiedzialności, co daje ogólny wynik 13,6\%. Jednak, jak przyznają sami pracownicy urzędu skarbowego, nie jest to wynik miarodajny. Te wyniki różnią się, niekiedy znacznie, w zależności od urzędu skarbowego. $Z$ obserwacji wynika, że w województwie śląskim spraw zakończonych dobrowolnym poddaniem się odpowiedzialności jest więcej w mniejszych miejscowościach niż w dużych aglomeracjach.

Jeżeli przywołać dane dotyczące całego kraju, to w 2009 r. na podstawie nieprawomocnych orzeczeń za przestępstwa skarbowe osądzono 8310 osób. W tej grupie 4536 osób dobrowolnie poddało się odpowiedzialności, a zatem więcej niż połowa (54,58\%). W całym $2010 \mathrm{r}$. nieprawomocnych orzeczeń zostało wydanych 10 872, z czego 5419 zakończyło się dobrowolnym poddaniem się odpowiedzialności, co daje ogólną sumę 49,84\%7.

W 2011 r. za przestępstwa skarbowe skazano 10299 osób, w tym 6542 skorzystało z omawianej instytucji (63,52\%). W tym roku zgromadzono również informacje dotyczące wykroczeń skarbowych. Spośród 24972 skazanych osób jedynie 9024 dobrowolnie poddało się odpowiedzialności, czyli uczyniło to $36,13 \%$ ukaranych.

W 2012 r. skazanych zostało 10722 osoby oraz ukarano 28422 osoby. Dobrowolnie poddało się odpowiedzialności odpowiednio 6547 i 9226

\footnotetext{
6 I. ZgolińsKi, op. cit., s. 251-257.

7 Dane udostępnione przez Ministerstwo Sprawiedliwości zawarte w piśmie z dnia 8 października 2013 r., znak DSD-II-06-66/13.
} 
osób (61,06\% w przypadku przestępstw skarbowych i 32,46\% w przypadku wykroczeń skarbowych).

W 2013 r. spośród 10455 skazanych za przestępstwa skarbowe 64,41\% dobrowolnie poddało się odpowiedzialności (6 735 osób), zaś spośród 38368 osób ukaranych za wykroczenia skarbowe było to 25,54\% (9 803 osób) ${ }^{8}$.

Z kolei 2014 r. nastąpił wzrost liczby przestępstw skarbowych. Ogółem skazano 11519 osób, z których tylko 56,37\% dobrowolnie poddało się odpowiedzialności (6 494 osób). Liczba wykroczeń również wzrosła do 60862 skazanych, przy jednoczesnym spadku osób korzystających z dobrowolnego poddania się odpowiedzialności do 13,5\% (8 220 osób).

Natomiast w 2015 r. liczba osób skazanych za przestępstwa skarbowe zmalała do 9990 osób. Pomimo że liczbowo nastąpił spadek osób zainteresowanych dobrowolnym poddaniem się odpowiedzialności (5 782 osób), proporcja ulega zwiększeniu do 57,87\%. W zakresie wykroczeń skarbowych utrzymała się tendencja z poprzedniego roku. Liczba osób skazanych wzrosła do 80344 osób (liczba ta jest ponad trzykrotnie wyższa w porównaniu z rokiem 2011) przy jednoczesnym spadku osób korzystających $\mathrm{z}$ dobrowolnego poddania się odpowiedzialności do 8,8\% (7 073 osób) $)^{9}$.

Istotne jest, że w odróżnieniu od wyroku wydanego w wyniku wniesienia do sądu aktu oskarżenia prawomocny wyrok udzielający zezwolenia na dobrowolne poddanie się odpowiedzialności nie podlega wpisowi do Krajowego Rejestru Karnego (art. $18 \$ 2 \mathrm{kks}$ ). W stosunku do sprawcy nie mają zatem zastosowania prawne skutki skazania, tj. konsekwencje ustalone bądź z mocy prawa, bądź przez właściwe organy ${ }^{10}$. Uiszczenie przez sprawcę określonej kwoty tytułem kary grzywny nie stanowi przesłanki recydywy skarbowej, określonej w art. $37 \$ 1$ pkt. 4 kks. Sprawca zatem w dalszym ciągu jest uznawany za osobę niekaraną.

8 Dane z lat 2011 - 2013 udostępnione przez Ministerstwo Sprawiedliwości zawarte w piśmie z dnia 18 czerwca 2014 r., znak DSD-061-147/14.

9 Dane za lata 2014 - 2015udostępnione przez Ministerstwo Sprawiedliwości zawarte w piśmie z dnia 15 lutego 2016 r., znak BM-II-061-124/16/1.

10 Uzasadnienie Rady Ministrów RP do projektu ustawy Kodeks karny skarbowy, [w:] Kodeks karny skarbowy z wprowadzeniem J. SoвCZAKA, Warszawa 1999, s. 152. 
Jest to szczególnie istotne w praktyce obrotu gospodarczego, ponieważ $\mathrm{w}$ wielu przypadkach przepisy wymagają dla prowadzenia określonej działalności, pełnienia określonej funkcji czy zajmowania stanowiska zachowania statusu niekaralności ${ }^{11}$.

Dopuszczalność stosowania tej instytucji doznaje jednak pewnych ograniczeń. Możliwość udzielenia zezwolenia na dobrowolne poddanie się odpowiedzialności jest wyłączone $\mathrm{w}$ przypadkach wymienionych $\mathrm{w}$ art. $17 \$ 2 \mathrm{kks}$. Jednym $\mathrm{z}$ negatywnych warunków jest zagrożenie przestępstwa skarbowego karą ograniczenia wolności albo karą pozbawienia wolności.

Dla niektórych przedstawicieli doktryny wydaje się dość oczywiste, dlaczego okoliczność, że przestępstwo skarbowe zagrożone karą ograniczenia wolności bądź jej pozbawienia wyłącza dopuszczalność zezwolenia na dobrowolne poddanie się odpowiedzialności. Zdaniem tych autorów sednem jest to, że ta instytucja jako rezultat negocjacji między organem procesowym a sprawcą bez udziału sądu, nie może wykraczać poza zagrożenie karą o dolegliwości ekonomicznej ${ }^{12}$. W przeciwnym razie w odbiorze społecznym mogłoby się pojawić wrażenie, że można kupić wolność za pieniądze ${ }^{13}$. Jednakże o tym, czy stanowisko to jest uzasadnione, czy też nie będzie decydował sposób rozumienia pojęcia „sprawiedliwości” na gruncie prawa karnego skarbowego. Wydaje się ono sprowadzać do odpowiedzi na pytanie, czy korzystniejsze jest ukaranie sprawcy (które często może wiązać się brakiem możliwości przeprowadzenia skutecznej egzekucji), czy też "puszczenie go wolno” w zamian za uregulowanie wszystkich zobowiązań oraz ewentualnie wymierzenie kary ekonomicznej.

W ocenie piszącego te słowa obecna sytuacja, w której znajduje się gospodarka (zwiększanie się długu publicznego, brak możliwości

\footnotetext{
11 A. BARtosiewicz, R. KubACKi, Zaniechanie ukarania sprawcy przestęstwa skarbowego, Warszawa 2003, s. 54.

12 M. Stepanów, Konsensualne rozstrzyganie w sprawach karnych skarbowych «Prokuratura i Prawo»11/2001, s. 68.

13 Z. Gostyński, Komentarz do kodeksu karnego skarbowego. Tytuł II. Postępowanie w sprawach o przestępstwa skarbowe i wykroczenia skarbowe. Tytuł III. Postępowanie wykonawcze, Warszawa 2000, s. 152.
} 
sfinansowanie podstawowych wydatków państwa, niska skuteczność egzekucji danin publicznych) zmusza nas do przyjęcia drugiego rozwiązania.

Zasadnym wydaje się zatem rozważenie rozszerzenia zakresu możliwości stosowania dobrowolnego poddania się odpowiedzialności również na czyny zagrożone karą ograniczenia oraz pozbawienia wolności. Oczywiście zastosowanie tej instytucji w przypadku tych czynów nie powinno odbywać się na takich samych zasadach, jak w przypadku czynów zagrożonych jedynie karą grzywny. Mam tu głównie na myśli brak wpisu do Rejestru Karnego. W takiej sytuacji zasadnym wydaje się wprowadzenie (być może nawet obligatoryjnego) zawieszenia wykonania kary na krótszy czas niż minimalny okres zawieszenia, jaki mógłby być orzeczony po rozpoznaniu sprawy na zasadach ogólnych. Jednocześnie należałoby się zastanowić nad skróceniem okresu, po jakim informacja o ukaraniu zostaje usunięta $\mathrm{z}$ Rejestru.

Procedura udzielenia zezwolenia na dobrowolne poddanie się odpowiedzialności składa się z dwóch etapów określanych $\mathrm{w}$ literaturze powszechnie jako faza negocjacyjna oraz faza decyzyjna (nazywana też niekiedy fazą jurysdykcyjną). Sama nazwa „negocjacje” razi niektórych autorów stojących na stanowisku, że kwestia winy czy okoliczności popełnienia czynu nie powinny być przedmiotem żadnych negocjacji sprawcy $\mathrm{z}$ organem procesowym ${ }^{14}$. Jednak należy podkreślić, że to nie te kwestie są tutaj przedmiotem negocjacji, lecz wyłącznie wysokość kwoty, jaka ma zostać uiszczona „tytułem kary grzywny”.

Pierwszą kwestią, która rodzi rozbieżne interpretacje, jest to, czy oprócz samego wniosku sprawca powinien złożyć również inne oświadczenia, w szczególności czy powinien przyznać się do winy.

Sama zgoda na poddanie się odpowiedzialności (a w prawie karnym powszechnym na skazanie) jest przez niektórych określana jako ekwiwalent przyznania się ${ }^{15}$. Dla innych już samo zgłoszenie wniosku

14 T. BoJARski, Kodeks karny skarbowy a kodeks karny. Kilka uwag porównawczych, [w]: Współczesne problemy procesu karnego i wymiaru sprawiedliwości. Księga ku czci Profesora Kazimierza Marszała, red. P. Hofmański, K. ZGRYZeK, Katowice 2003, s. 46.

15 K. LewCzuk Targ o wine i karę? Porozumienie w polskim procesie karnym $\mathrm{Pa}$ lestra 47.3-4/2002, s. 25; T. GRZEGORCZy Kodeks postępowania karnego Warszawa 
jest równoznaczne z przyznaniem się do popełnienia zarzucanego mu czynu $^{16}$. Autor tego poglądu wskazuje, że $\mathrm{z}$ tego powodu ustawodawca osobę zgłaszającą wniosek określa mianem „sprawcy”. Konieczne jest jednak również odnotowanie poglądu wyrażonego na gruncie powszechnego prawa karnego, że zastosowanie regulacji art. $335 \mathrm{kpk}$ oraz $387 \mathrm{kpk}$ zbliżonych w swej istocie do karnoskarbowej instytucji dobrowolnego poddania się odpowiedzialności, powinno mieć miejsce tylko wówczas, gdy oskarżony przyznał się do winy ${ }^{17}$. W sytuacji zaś, gdy oskarżony nie przyznaje się do popełnienia zarzucanego mu czynu, problematyczne jest przyjęcie, że okoliczności popełnienia czynu nie budzą wątpliwości ${ }^{18}$. Poglądy te zostały wyrażone przed nowelizacją, która weszła w życie z dniem 1 lipca 2015 r. ${ }^{19}$ Obecna regulacja art. 335 kpk wymaga już przyznania się do winy. Jednakże nowelizacja nie objęła regulacji dotyczących dobrowolnego poddania się odpowiedzialności, co powoduje, że problem pozostaje nadal aktualny.

Zarówno zatem organ finansowy, jak i sąd powinny ocenić materiał dowodowy w kontekście oświadczenia dowodowego (wyjaśnień) podejrzanego i na ich podstawie, a nie na jego wniosek o zezwolenie na dobrowolne poddanie się odpowiedzialności, ustalić, czy spełniony jest warunek wynikający $\mathrm{z}$ art. $17 \S 1 \mathrm{kks}$, a dotyczący jasności co do winy i sprawstwa wnioskującego ${ }^{20}$. Nie można zresztą wykluczyć, że zdarzy się, że sprawca nie przyznający się do winy zdecyduje się na wyrażenie zgody na skazanie ze względów czysto taktycznych, gdy dojdzie do wniosku, że lepiej opłaci mu się przyjąć ofertę łagodnego skazania niż

1998, s. 669.

16 D. ŚwIEcki, Dobrowolne poddanie się odpowiedzialności w kodeksie karnym skarbowym «Przegląd Sądowy» 3/2001, s. 99.

17 E. KRUK, Kilka uwag na temat stosowania art. 335 i art. 387 kodeksu postępowania karnego, «Prokuratura i Prawo» 1/2000, s. 88.

18 P. Hofmański, E. SAdZik, K. ZgRYZeK, Kodeks postępowania karnego. Komentarz, II, Warszawa 1999, s. 359

19 Ustawa z dnia 20 lutego 2015 r. o zmianie ustawy - Kodeks karny oraz niektórych innych ustaw Dz. U. 2015, nr 396.

20 T. Grzegorczy , Kodeks karny skarbowy. Komentarz, Warszawa 2006, s. 154. 
ryzykować długotrwały proces z niepewnym wynikiem ${ }^{21}$. W literaturze słusznie przy tym podnosi się, że w praktyce mogą wystąpić różne sytuacje. Sprawca może bowiem przyznać się do zarzucanego mu czynu, a następnie odmówić składania wyjaśnień. Może przyznać się, ale treść jego wyjaśnień może przeczyć przyznaniu. Wreszcie może nie przyznać się, ale złożone wyjaśnienia będą jednoznaczne z przyznaniem się i wyjaśnieniem wszystkich okoliczności sprawy. Oznacza to z jednej strony brak racjonalnych powodów do demonizowania znaczenia i roli przyznania się sprawcy do popełnienia zarzucanego mu przestępstwa (wykroczenia) skarbowego, a $z$ drugiej powoduje uznanie, że niewątpliwie uproszczenie całego postępowania, jakie wynika z zastosowania instytucji dobrowolnego poddania się odpowiedzialności, nigdy nie może być dokonane $\mathrm{z}$ naruszeniem zasady prawdy ${ }^{22}$.

Przychylić się należy do stanowiska, że dobrowolność poddania się odpowiedzialności nie zakłada wyraźnego przyznania się do winy, jednakże pozwala na stwierdzenie, że sprawca nie zaprzecza faktowi popełnienia przestępstwa. Przyznanie się nie jest konieczną przesłanką, najważniejsza jest natomiast zgoda sprawcy, która musi być dobrowolna ${ }^{23}$.

Potwierdza to również Sąd Najwyższy, który przyznaje, że sam fakt złożenia przez sprawcę wniosku nie przesądza o jego winie czy sprawstwie. Powinny one wynikać z całokształtu okoliczności sprawy. Nie wymaga się tu wyraźnie przyznania się sprawcy do winy, ale przy braku przyznania należy tym bardziej wnikliwie i ostrożnie ocenić zebrany materiał dowodowy, choć jest równie oczywiste, że samo przyznanie też nie przesądza automatycznie o sprawstwie i winie przyznającego się. Zarówno zatem organ finansowy, jak i sąd powinny ocenić materiał dowodowy w kontekście oświadczenia dowodowego (wyjaśnień) podejrzanego i na ich podstawie, a nie na jego wniosek o zezwolenie

21 S. WALtoś, Nowe instytucje w kodeksie postępowania karnego z 1997 r., «PiP» 50.8/1997, s. 27 - autor przedstawił ten pogląd omawiając instytucję wynikającą z art. 335 kpk.

22 P. Kardas, G. Łabuda, T. Razowski, Kodeks karny skarbowy, Komentarz, Warszawa 2010, s. 274-275.

23 F. Prusak, op. cit., s. 15. 
na poddanie się karze, ustalić, czy spełniony jest warunek wynikający $\mathrm{z}$ art. $17 \S 1$, a dotyczący jasności co do winy i sprawstwa wnioskującego ${ }^{24}$.

Jeżeli wniosek składany jest w formie pisemnej, to wówczas, jak każde pismo procesowe, musi spełniać określone wymogi formalne przewidziane w art. $119 \$ 1 \mathrm{kpk} \mathrm{w} \mathrm{zw.} \mathrm{z} \mathrm{art.} 113 \S 1 \mathrm{kks}^{25}$.

Dodatkowe wymogi formalne wniosku wyszczególnione zostały w $142 \$ 4$ kks w zw. z art. art. $143 \$ 1-3$ kks. Składając wniosek, sprawca musi zatem dołączyć dowód:

1. uiszczenia należności publicznoprawnej, jeżeli w związku z przestępstwem skarbowym lub wykroczeniem skarbowym nastąpiło uszczuplenie tej należności, chyba że do chwili zgłoszenia wniosku ta wymagalna należność została w całości uiszczona;

2. uiszczenia tytułem kary grzywny kwoty odpowiadającej co najmniej jednej trzeciej minimalnego wynagrodzenia, a za wykroczenie skarbowe - kwoty odpowiadającej co najmniej jednej dziesiątej tego wynagrodzenia;

3. co najmniej zryczałtowaną równowartość kosztów postępowania.

Jeżeli badać relację pomiędzy przepisem art. $17 \$ 1 \mathrm{kks}$ a art. 143 kks, to spotkać się można z poglądem, że ten ostatni przepis powtarza warunki zastosowania insty tucji dobrowolnego poddania się odpowiedzialności, co określa się mianem „nadregulacji”. ${ }^{26}$ Nie wydaje się to być do końca słusznym stanowiskiem, albowiem art. $17 \$ 1$ kks określa tzw. „warunki brzegowe”, czyli to minimum, które sprawca musi spełnić, aby sąd mógł wydać zezwolenie na dobrowolne poddanie się odpowiedzialności. Stanowisko to znajduje odzwierciedlenie w orzecznictwie Sądu Najwyższego, który uznał, że warunki na gruncie art. 17 kks nie są tylko warunkami skutecznego złożenia wniosku, lecz warunkami dopuszczalności wydania orzeczenia o zastosowaniu instytucji zaniechania

24 Postanowienie z dnia 25 maja 2005 r., III KK 84/05, «Lex» nr 151686.

25 Oznaczenie organu, do którego jest skierowane, oraz sprawy, której dotyczy, oznaczenie oraz adres wnoszącego pismo, treść wniosku lub oświadczenia, w miarę potrzeby z uzasadnieniem, datę i podpis składającego pismo. Przy czym za osobę, która nie może się podpisać, pismo podpisuje osoba przez nią upoważniona, ze wskazaniem przyczyny złożenia swego podpisu.

26 T. GrZegorCZy K Kodeks karny skarbowy..., s. 138. 
ukarania, jaką jest m.in. dobrowolne poddanie się odpowiedzialności ${ }^{27}$. Z kolei art. 143 kks przewiduje „warunki brzegowe” wniosku o udzielenie takowego zezwolenia, czyli to minimum, jakie sprawca musi spełnić, żeby mogły rozpocząć się negocjacje $\mathrm{z}$ organem procesowym co do ostatecznych warunków, na jakich sprawa karna skarbowa zostanie zakończona. Przy czym, w tym ostatnim przypadku należałoby się raczej posługiwać występującym zarówno w literaturze, jak i w orzecznictwie, terminem „warunki brzegowe negocjacji”28.

Odpowiedzi wymaga pytanie, jak należy traktować sytuację, gdy sprawca nie dołączył do swojego wniosku dowodów wykonania obowiązków wymienionych w art. $143 \$ 1-3 \mathrm{kks}$. Literalnie rzecz ujmując, powinno to zostać potraktowane jako brak formalny wniosku, zwłaszcza gdy sprawca uiścił wszystkie należne kwoty, a jedynie nie dołączył do wniosku dowodu zapłaty. Gdyby bardzo rygorystycznie interpretować przepisy, można byłoby uznać, że w sytuacji, gdy sprawca nie zapłacił, czyli nie spełnił warunków brzegowych negocjacji, to nie ma podstaw do ich wszczęcia, a co za tym idzie, do wezwania do uzupełnienia braków. Opowiedzieć się jednak należy za bardziej liberalnym stanowiskiem (podyktowanym bez wątpienia racjonalnością w prowadzeniu postępowania, a także ze względu na omawiany tu priorytet celu egzekucyjnego), że należy dopuścić wyznaczenie sprawcy określonego terminu do dokonania czynności wymienionych w art. $143 \$ 1-3 \mathrm{kks}$, zwłaszcza że często dopiero w chwili składania wniosku finansowy organ dochodzenia będzie precyzował konkretne obowiązki, jakie powinien wykonać sprawca. Dopiero po bezskutecznym upływie zakreślonego terminu do ich wykonania konieczne będzie wydanie postanowienia o odmowie wniesienia wniosku ${ }^{29}$.

27 Uchwała Sądu Najwyższego z dnia 25 października 2000 r., I KZP 24/00 «OSNKW»11-12/2000, s. 96.

28 Dla przykładu D. ŚwIECKI, op. cit., s. 92 czy wskazana w poprzednim przypisie uchwała Sądu Najwyższego.

29 D. ŚWIECKI, op. cit., s. 93. Autor nie wskazuje przy tym, czy należy rozumieć tutaj termin jako siedmiodniowy. Przy jego wyznaczaniu należałoby się jednak posiłkować wytycznymi zawartymi w art. 14 kks i dostosować termin do możliwości finansowych sprawcy. 
W literaturze spotkać można niejednoznaczne stanowisko w tej kwestii. W jednym $z$ komentarzy wyrażono pogląd, że w praktyce dowody te składane są po wystąpieniu przez sprawcę $\mathrm{z}$ wnioskiem o zezwolenie na dobrowolne poddanie się odpowiedzialności - w takim jednak terminie, aby w ramach prowadzonego postępowania przygotowawczego umożliwić właściwemu finansowemu organowi postępowania przygotowawczego przygotowanie wniosku o udzielenie zezwolenia na dobrowolne poddanie się odpowiedzialności, który podlega złożeniu w sądzie. Niedopełnienie przez sprawcę wymogu dołączenia do wniosku dowodów wykonania czynności wymienionych w art. $143 \$ 1-3$ kks stanowi brak formalny, podlegający usunięciu w trybie art. 143a kks ${ }^{30}$. Dalej ten sam autor argumentuje, że jeżeli wniosek nie spełnia warunków z art. 143 $\$-3 \mathrm{kks}$, a zatem jeżeli nie dołączono do niego dowodu uiszczenia całości uszczuplonej należności publicznoprawnej, stosownej kwoty tytułem grzywny, co najmniej zryczałtowanej równowartości kosztów postępowania oraz zgody na przepadek przedmiotów, to merytoryczne ustosunkowanie się do niego jest możliwe - po prostu finansowy organ postępowania przygotowawczego powinien wydać zaskarżalne postanowienie o odmowie skierowania do sądu wniosku o udzielenie zezwolenia na dobrowolne poddanie się odpowiedzialności ${ }^{31}$.

Zasadna wydaje się jednak zmiana art. $143 \$ 1$ pkt. 1 kks poprzez zastąpienie wymogu uiszczenia należności publicznoprawnej łącznie $\mathrm{z}$ wnioskiem o dobrowolne poddanie się odpowiedzialności wymogiem uiszczenia jej w terminie wyznaczonym przez uprawniony organ. Dotychczasowy wymóg może stanowić pewną przeszkodę w stosowaniu tej instytucji. niejednokrotnie sprawca ma możliwość i wyraża wolę dopełnienia tego warunku, jednakże nie jest w stanie uczynić tego łącznie ze składanym wnioskiem. W praktyce organy postępowania przygotowawczego często wyznaczają dodatkowy termin, nie mając jednakże do tego podstawy prawnej. Oczywiście nie wszystkie stosują taką praktykę. Niekiedy, gdy sprawca złoży wniosek bez uiszczenia uszczuplonej należności publicznoprawnej, od razu odmawiają przyjęcia

\footnotetext{
30 P. Kardas, G. Łabuda, T. Razowski, op. cit., s. 983.

31 P. Kardas, G. Łabuda, T. Razowski, op. cit., s. 988-989.
} 
wniosku (trzymając się litery prawa, lecz godząc w ideę instytucji). Nie dają przez to sprawcy szansy na skorzystanie $\mathrm{z}$ dobrowolnego poddania się odpowiedzialności, które niejednokrotnie byłoby możliwe, gdyby dać sprawcy pewien czas na dopełnienie warunku fiskalnego, tak jak to jest w przypadku czynnego żalu (art. $16 \$ 2 \mathrm{kks}$ ).

W sytuacji, gdy wniosek sprawcy składany jest wobec organu niefinansowego, to wówczas sprawa jest przekazywana organowi finansowemu, bowiem tylko temu ostatniemu kks przyznaje prawo do negocjowania warunków, na których zostanie złożony wniosek do sądu (art. $134 \$ 4$ $\mathrm{kks})$.

Złożenie wniosku przez sprawcę stanowi dopiero propozycję konsensualnego zakończenia sprawy skierowaną wobec finansowego organu postępowania przygotowawczego i mimo spełnienia warunków brzegowych negocjacji nie musi ona zostać zaakceptowana przez organ finansowy ${ }^{32}$.

W orzecznictwie Sądu Najwyższego dotyczącego art. 387 kpk (instytucji dobrowolnego poddania się odpowiedzialności karnej) zajęto stanowisko, że przychylenie się sądu do wniosku oskarżonego o wydanie wyroku skazującego na zasadach przewidzianych w art. $387 \$ 1$ i 2 k.p.k. zobowiązuje sąd do wymierzenia kary zgodnej z akceptowanym wnioskiem. Orzeczenie przez sąd kary surowszej (lub środka karnego nie przewidzianego we wniosku) oznacza złamanie „swoistej ugody” określającej warunki dobrowolnego poddania się karze i tym samym stanowi podstawę do kasacji (art. 523 k.p.k.), gdyż jest rażącym naruszeniem prawa procesowego, mającym istotny wpływ na treść orzeczenia ${ }^{33}$.

Do nowelizacji z 2005 r. sąd, rozpatrując wniosek finansowego organu dochodzenia, miał możliwość zmniejszenia kwoty uiszczanej przez sprawcę w stosunku do wartości proponowanej w treści wniosku ${ }^{34}$.

32 H. Skwarczyński Dobrowolne poddanie się odpowiedzialności w Kodeksie karnym skarbowym, «Monitor podatkowy» 4/2006, s. 29.

33 Wyrok z dnia 7 września 1999 r. WKN 32/99 «OSNKW» 1999/11-12/77 z glosą W. Marcinkowskiego, «Wojskowy Przegląd Prawniczy» 3-4/2001, s. 149

34 Art. 18. \$1 pkt. 1 sprzed nowelizacji miał następujące brzmienie: „Sąd, udzielając zezwolenia na dobrowolne poddanie się odpowiedzialności, orzeka tytułem kary grzywny kwotę nie wyższą niż uiszczona przez sprawcę". 
Obecnie sąd uprawniony jest wyłącznie do akceptacji wniosku w jego niezmienionym kształcie bądź też do odmowy jego uwzględnienia. Pozbawienie sądu prawa do modyfikacji wniosku, gdy uznaje, że kara jest zbyt wygórowana w stosunku do winy sprawcy (lub też zapewne rzadziej zbyt niska), jest bez wątpienia wyrazem realizacji idei priorytetu egzekucji nad represją w postępowaniu karnym skarbowym. Tak więc w sytuacji, gdy sąd uzna, że uzgodnione w toku negocjacji warunki dobrowolnego poddania się odpowiedzialności są nieadekwatne do wagi czynu, jego społecznej szkodliwości czy winy sprawcy, zwraca sprawę finansowemu organowi postępowania przygotowawczego, ponieważ przepisy nie pozwalają sądowi na uzależnienie wydania zezwolenia od modyfikacji ustaleń poczynionych pomiędzy organem finansowym a sprawcą ${ }^{35}$.

Takie rozwiązanie przyjęte przez ustawodawcę nie spotkało się z aprobatą komentatorów. Wskazują oni, że nie można wykluczyć sytuacji, w której finansowy organ postępowania przygotowawczego po dokonanym zwrocie podejmie decyzję o odstąpieniu od ponownego skierowania do sądu takiego wniosku, tylko złoży w nim akt oskarżenia. W efekcie dojdzie do pogorszenia sytuacji procesowej sprawcy. W konsekwencji przedstawione rozwiązanie $\mathrm{w}$ pewnych wypadkach może generować sytuacje o charakterze antygwarancyjnym, co dodatkowo podkreśla jego wadliwośćc ${ }^{36}$. Przyznać należy rację T. Razowskiemu, że brak jest jakichkolwiek, osadzonych w teorii prawa i mających uzasadnienie praktyczne przeszkód do tego, aby wzorem skazania bez rozprawy i dobrowolnego poddania się odpowiedzialności karnej, również w razie orzekania przez sąd o udzieleniu zezwolenia na dobrowolne poddanie się odpowiedzialności dopuścić możliwość modyfikacji przez strony wniosku w tym przedmiocie, w tym inspirowanej przez sąd. Poza tym istota porozumień procesowych wcale nie zamyka się $\mathrm{w}$ fazie ustalania ich treści, lecz, co do zasady, przenosi się również do fazy orzekania w przedmiocie udzielenia na nie zezwolenia, niezależnie od jego postaci. Czym innym jest bowiem zawarcie porozumienia, a czym innym

\footnotetext{
A. Bartosiewicz, R. Kubacki, op. cit., s. 52.

36 P. Kardas, G. Łabuda, T. RazowsKi, op. cit., s. 299-300.
} 
możliwość jego modyfikacji, otwierającej pole do pełnej realizacji interesów obu stron, przy baczeniu sądu na ich normatywną i sprawiedliwościową poprawnośćc ${ }^{37}$.

Jeżeli zdaniem sądu wniosek zasługuje na uwzględnienie, to udzielając zezwolenia na dobrowolne poddanie się odpowiedzialności sąd wydaje w tej kwestii wyrok (art. $148 \$ 5$ kks). Do nowelizacji z 2005 r., uwzględniając wniosek, sąd rozstrzygał postanowieniem, jednakże regulacja ta wymagała zmiany, ponieważ w myśl art. 42 ust. 3 Konstytucji przypisanie odpowiedzialności karnej możliwe jest wyłącznie na podstawie wyroku. Przychylając się do wniosku, sąd powinien uznać za ujawnione dowody wymienione $\mathrm{w}$ nim, ewentualnie dokumenty przedłożone przez stronę, gdyż będzie wyrokował na podstawie tych właśnie, a nie bezpośrednio przeprowadzanych dowodów ${ }^{38}$. Uznanie tych dowodów za ujawnione jest niezbędne $\mathrm{z}$ uwagi na wymogi określone w art. $410 \mathrm{kpk}$, tj. oparcie wyroku na całokształcie ujawnionych na rozprawie okoliczności ${ }^{39}$.

Jeżeli sąd odmawia udzielenia zgody na dobrowolne poddanie się odpowiedzialności przez sprawcę, to wówczas niezwłocznie zwraca sprawę finansowemu organowi postępowania przygotowawczego, wydając w tym zakresie odpowiednie postanowienie (art. $148 \$ 6 \mathrm{kks}$ ). W takim wypadku sąd powinien bardzo wyraźnie określić, z jakich przyczyn dokonał zwrotu sprawy. Wówczas, jeśli organ finansowy przychyli się do stanowiska sądu, będzie mógł ponownie złożyć wniosek. Można spotkać przeciwny głos prezentowany w literaturze, stwierdzający, że postanowienie sądu definitywnie kończy postępowanie zainicjowane wnioskiem sprawcy, co oznacza, że organ finansowy nie może na podstawie tego samego wniosku sprawcy wnieść do sądu wniosku o udzielenie zezwolenia na dobrowolne poddanie się odpowiedzialności ${ }^{40}$. Brak jest jednak przekonujących podstaw do pozbawienia sprawcy możliwości skorzystania z dobrodziejstwa instytucji dobrowolnego poddania się

\footnotetext{
37 Ibidem, s. 300-301.

38 P. RogozIŃsKi, O niektórych procesowych aspektach dobrowolnego poddania sie przez oskarżonego odpowiedzialności karnej (art. 387 kpk) «Palestra» 46.1-2/2001, s. 13.

39 P. Hofmański, E. SAdZIK, K. ZGRYZEK, op. cit. s. 508.

40 Z. GostYŃsKi, op. cit., s. 242.
} 
odpowiedzialności, jeżeli tylko przyczyny odmowy nie są tego rodzaju, że nie ma możliwości ich usunięcia w toku negocjacji.

Wskazane przed chwilą okoliczności nie są oczywiście jedynymi przyczynami odmowy uwzględniania wniosku. Wśród pozostałych wymienia się przede wszystkim brak spełnienia warunków do udzielenia zezwolenia, co ma miejsce, gdy:

1. wina sprawcy i okoliczności popełnienia czynu budzą wątpliwości,

2. uiszczona kwota jest niższa niż najniższa kwota grożąca za dany czyn,

3. uiszczone kwoty nie pokryły w całości uszczuplonej należności publicznoprawnej,

4. nie złożono przedmiotów, mimo obowiązkowego ich przepadku, jak również nie uiszczono ich równowartości,

5. po wniesieniu wniosku do sądu została zgłoszona interwencja co do przedmiotów podlegających przepadkowi i interwencji tej nie wycofano,

6. popełniony czyn jest zagrożony karą ograniczenia wolności bądź pozbawienia wolności albo popełniono go w warunkach uzasadniających nadzwyczajne obostrzenie kary ${ }^{41}$.

Tymczasem na gruncie powszechnego prawa karnego sąd, rozpoznając wniosek o skazanie oskarżonego bez rozprawy (art. $343 \$ 3 \mathrm{kpk}$ ) lub też wniosek o skazanie oskarżonego bez prowadzenia postępowania dowodowego (art. $387 \$ 3 \mathrm{kpk}$ ), ma możliwość uzależnienia zezwolenia od modyfikacji wniosku lub nałożenia na oskarżonego dodatkowych zobowiązań.

Pomimo że sens instytucji dobrowolnego poddania się odpowiedzialności polega na uproszczeniu postępowania z korzyściami zarówno dla sprawcy, jak i wymiaru sprawiedliwości, tym niemniej ustawodawca uznał za konieczne wprowadzenie możliwości zaskarżenia wyroku o zezwoleniu na dobrowolne poddanie się odpowiedzialności ${ }^{42}$. W art. 149 $\$ 1$ pkt 1 i 2 kks wskazano dwie podstawy pozwalające na uchylenie lub

\footnotetext{
A. Bartosiewicz, R. Kubacki, op. cit., s. 52.

42 G. Skowronek, Dobrowolne poddanie się odpowiedzialności na gruncie kodeksu karnego skarbowego, «Prokuratura i Prawo» 3/2005, s. 163.
} 
zmianę wyroku sądu I instancji. Może to mianowicie nastąpić wówczas, gdy sąd orzekł tytułem kary grzywny kwotę inną niż uiszczona przez sprawcę lub przepadek przedmiotów, lub uiszczenie ich równowartości pieniężnej w zakresie nieobjętym zgodą sprawcy. Wymienione przesłanki mają charakter gwarancyjny, zabezpieczający sprawcę przestępstwa skarbowego bądź wykroczenia skarbowego przed poniesieniem nadmiernej odpowiedzialności niż wynikająca $\mathrm{z}$ art. $18 \S 1 \mathrm{kks}^{43}$.

W piśmiennictwie spotkać można zapatrywanie, że przepis art. 149 kks jest przepisem szczególnym, co wyklucza, w myśl art. $113 \$ 1$ kks, możliwość uchylenia lub zmiany orzeczenia na innej podstawie ${ }^{44}$. Przeważa jednak stanowisko o dopuszczalności stosowania również przepisów art. 439 kpk (bezwzględne przyczyny odwoławcze), 440 kpk (rażąca niesprawiedliwość wyroku) oraz 455 kpk (błędna kwalifikacja prawna) ${ }^{45}$.

Na gruncie przepisów kodeksu postępowania karnego regulujących porozumienia procesowe nie występują ograniczenia w możliwości zaskarżenia orzeczeń. Rozstrzygając na przykład zagadnienia związane ze stosowaniem art. $387 \mathrm{kpk}$, Sąd Najwyższy przyjął, że orzeczenie przez sąd kary surowszej (lub środka karnego nieprzewidzianego we wniosku) oznacza złamanie „swoistej ugody” określającej warunki dobrowolnego poddania się karze i tym samym stanowi podstawę do kasacji, gdyż jest rażącym naruszeniem prawa procesowego mającym wpływ na treść orzeczenia. W uzasadnieniu Sąd argumentował, że godząc się na ten tryb postępowania sądowego swoistą ugodą co do dobrowolnego poddania się karze, sąd orzekający jest związany swą wcześniejszą decyzją w tym przedmiocie, dlatego też czynienie w wyroku jakiejkolwiek zmiany jest niedopuszczalne ${ }^{46}$. Niektórzy precyzują przy tym, że należy rozumieć tu nie tylko niedopuszczalność rozstrzygnięcia, które byłoby na niekorzyść

\footnotetext{
43 V. Konarska-Wrzosek, T. Oczkowski, J. Skorupka, Prawo i postępowanie karne skarbowe, Warszawa 2010, s. 376.

44 Z. GostyńsKi, op. cit., s. 243-244.

45 L. Wilk, J. ZaGrodnik Kodeks, op. cit., s. 725-726; J. SAWICKI, op. cit., s. 270.

46 Wyrok z 7 września 1999 r. WKN 32/99, «OSNKW»11-12/1999, poz. 77.
} 
oskarżonego, ale i w jego interesie, tzn. wydany wyrok przewidywałby karę łagodniejszą niż wcześniej orzeczona ${ }^{47}$.

Uwzględniając apelację, sąd odwoławczy może uchylić zaskarżony wyrok bądź go zmienić, oczywiście jeśli wystąpiły przesłanki wymienione w art. $149 \$ 1$ pkt. 1 i 2 kks. Zmieniając zaskarżony wyrok, sąd nie może ignorować porozumienia sprawcy $\mathrm{z}$ finansowym organem postępowania przygotowawczego, co oznacza, że nie może obniżyć kwoty uiszczonej przez sprawcę tytułem grzywny poniżej wpłaconej (ustalonej w negocjacjach) ani nie może orzec przepadku przedmiotów (nakazać uiszczenia ich równowartości) w mniejszym zakresie, niż wynikało to ze zgody sprawcy ${ }^{48}$. Nie można także wykluczyć sytuacji umorzenia postępowania, w warunkach $\mathrm{z}$ art. $439 \$ 1$ pkt. 9 kpk w zw. $\mathrm{z}$ art. $113 \$ 1 \mathrm{kks})$.

Postanowienie odmowne w przedmiocie wniosku o udzielenie zezwolenia na dobrowolne poddanie się odpowiedzialności jest natomiast niezaskarżalne (art. $459 \$ 1 \mathrm{kpk}$ w zw. z art. $113 \S 1 \mathrm{kks})^{49}$. Nie należy bowiem do postanowień, które zamykają drogę do wydania wyroku ${ }^{50}$.

Dodatkowo, w przypadku odmowy uwzględnienia wniosku, analogicznie jak w przypadku cofnięcia wniosku, uiszczone przez sprawcę kwoty zatrzymuje się do zakończenia postępowania jako zabezpieczenie grożących mu kar, środków karnych lub innych środków oraz kosztów postępowania. Rozwiązanie takie wprawdzie ułatwia egzekucję uszczuplonych należności, jednakże może okazać się pewnym hamulcem dla praktyki dobrowolnego poddania się odpowiedzialności ${ }^{51}$.

Reasumując, dobrowolne poddanie się odpowiedzialności jest jedną z najczęściej stosowanych i najbardziej preferowanych przez

47 M. Zвrojewska, Dobrowolne poddanie się karze w świetle orzecznictwa Sądu Najwyższego, "Przegląd Sądowy»11-12/2001, s. 209.

48 P. Kardas, G. Łabuda, T. Razowski Kodeks karny ... op. cit. s. 1026.

49 C. Kulesza, Glosa do uchwały SN z 25 października 2000 r., I KZP 24/2000, «OSNKW» 11-12/2000, poz. 96; «Prokuratura i Prawo» 7-8/2001, s. 108, F. PrusaK, op. cit., s. 1092.

50 T. Grzegorczy K, Kodeks karny skarbowy..., s. 609.

51 K. SzczePański Postępowanie karne skarbowe (projekt uks), «Prawo i Życie» 21/1970, s. 3. 
ustawodawcę instytucji łagodzenia odpowiedzialności karnoskarbowej. Nie jest to jednak instytucja wolna od wad. Proponowane zmiany maja na celu ich usunięcie, a jednocześnie rozszerzenie możliwości stosowania tej instytucji w celu wzmocnienia egzekucyjnej funkcji prawa karnego skarbowego.

\section{Voluntary Acceptance of Liability in Fiscal Criminal Law. REMARKS ON RELEVANT LEgISLATION}

\section{Summary}

Voluntary acceptance of liability is one of the most commonly used institutions for the reduction of fiscal criminal liability. The purpose of this study is to answer question whether the current regulations are working efficiently, or whether modification is needed.

Słowa kluczowe: odpowiedzialność karnoskarbowa; dobrowolne poddanie się odpowiedzialności; naprawienie szkody.

Keywords: penal and fiscal liability; voluntary submission to liability; redress of damage.

\section{Literatura:}

Bartosiewicz Adam, Kubacki Ryszard, Zaniechanie ukarania sprawcy przestępstwa skarbowego, Warszawa 2003, s. 52-54

BoJARSKI TADEUSz, Kodeks karny skarbowy a kodeks karny. Kilka uwag porównawczych, [w]: Wspótczesne problemy procesu karnego i wymiaru sprawiedliwości. Księga ku czci Profesora Kazimierza Marszała, red. Hofmańsкi Piotr, Zgryzek Kazimierz, Katowice 2003, s. 46

Gostyński ZBigniew Komentarz do kodeksu karnego skarbowego. Tytuł II. Postępowanie w sprawach o przestępstwa skarbowe i wykroczenia skarbowe. Tytuł III. Postępowanie wykonawcze, Warszawa 2000, s. 152

Grzegorczy K Tomasz, Kodeks karny skarbowy Komentarz, Warszawa 2006, s. 138,154

GrZegorczy K Tomasz, Kodeks postępowania karnego Warszawa 1998, s. 669 Hofmański Piotr, Sadzik Elżbieta, Zgryzek Kazimierz, Kodeks postępowania karnego. Komentarz, II, Warszawa 1999, s. 359 
Kardas Piotr, Łabuda Grzegorz, Razowski Tomasz, Kodeks karny skarbowy, Komentarz, Warszawa 2010, s. 274-275

Konarska-Wrzosek Violetta, Oczkowski Tomasz, Skorupka Jerzy, Prawo i postępowanie karne skarbowe, Warszawa 2010, s. 376

KRUK Ewa, Kilka uwag na temat stosowania art. 335 i art. 387 kodeksu postępowania karnego, «Prokuratura i Prawo» 1/2000, s. 88

Kulesza Cezary, Glosa do uchwały SN z 25 października 2000 r., I KZP 24/2000, «OSNKW» 11-12/ 2000, poz. 96; «Prokuratura i Prawo» 7-8/2001, s. 108

Lewczuk Krzysztof Targ o wine i karę? Porozumienie w polskim procesie karnym «Palestra» 47.3-4/2002, s. 25

Prusak Feliks, Normatywne i pragmatyczne aspekty dobrowolnego poddania się karze, «Nowe Prawo» 3/1980, s. 14

RogOzińsKi PIOTR, O niektórych procesowych aspektach dobrowolnego poddania się przez oskarżonego odpowiedzialności karnej (art. 387 kpk), «Palestra» 46.1-2/2001, s. 13

SAWICKI JANUSZ RYSZARD, Zaniechanie ukarania jako element polityki karnej w prawie karnym skarbowym, WROCŁAW 2011

SKowronek Grzegorz, Dobrowolne poddanie się odpowiedzialności na gruncie kodeksu karnego skarbowego, «Prokuratura i Prawo» 3/2005, s. 163

SKWARCZYŃski Hubert, Dobrowolne poddanie się odpowiedzialności w Kodeksie karnym skarbowym, «Monitor podatkowy» 4/2006, s. 29

STEPANów Monika, Konsensualne rozstrzyganie w sprawach karnych skarbowych «Prokuratura i Prawo»11/2001, s. 68

SzCZEPański KaZIMIERZ, Postępowanie karne skarbowe (projekt uks), «Prawo i Życie» 21/1970, s. 3

ŚwIECKi Dariusz, Dobrowolne poddanie się odpowiedzialności w kodeksie karnym skarbowym, «Przegląd Sądowy» 3/2001, s. 99

Waltoś Dariusz, Nowe instytucje w kodeksie postępowania karnego z $1997 \mathrm{r}$., «Państwo i Prawo» 50.8/1997, s. 27

Wilk Leszek, Zagrodnik JarosŁaw, Kodeks karny skarbowy. Komentarz, WARSZAWA 2007, s. 89-90

Zвrojewska Monika, Dobrowolne poddanie się karze w świetle orzecznictwa Sąu Najwyższego, «Przegląd Sądowy»11-12/2001, s. 209

ZGoliŃski IGOR, Dobrowolne poddanie się odpowiedzialności w prawie karnym skarbowym, WARSZAWA 2011, s. 17-60 